Anna Leskinen*

\title{
Methodological Issues in Studies of Cultural Legacies in Post-Socialist Russia's Civil Society
}

\begin{abstract}
The state of civil society in post-socialist Russia and other former socialist countries is of great interest to social scientists, policy makers, and development-oriented practitioners. Numerous theoretical assumptions and methodological approaches have been used by researchers to describe, analyze, and assess the state of civil society in Russia, for example. One of the key issues addressed has been the influences on citizens' civic and social activities and the historical conditions and cultural environments that have generated - and continue to generate - these activities. This critique focuses on the concept of "communist legacies" which has been applied at the individual level to explain people's preferences, attitudes, and forms of behavior in Russia and other postsocialist countries. The concept is influential, in large part, because it has been supported by empirical research, especially the highly influential empirical research of Marc Howard. This paper takes a critical look at this research, including its theoretical frame and the methodology associated with the frame.
\end{abstract}

Keywords: civil society, Russia, communist legacies, cultural legacies, methodology

\section{Methodological Issues in Studies of Cultural Legacies in Post-Socialist Russia's Civil Society}

In the early 1990s, political reformers anticipated a comprehensive transition of socialist Russia into a democratic capitalist country. A common assumption was that, in order to succeed in economic and political development, the former socialist countries such as Russia needed to follow the "Western liberal model" with its emphasis on a free market economy, private property, civil liberties, the rule of law, and a relatively weak government (e.g. see Carothers 2002; Sakwa

*Corresponding author: Anna Leskinen, SOLES, University of San Diego, 5998 Alcala Park, San Diego, CA 92110-2492, USA, E-mail: aleskinen@sandiego.edu 
2012). However, the last 20 years have evidenced a failure of Western type democracy and the development of authoritarian trends in Russia (Evans 2011). In addition, civil society organizations in post-Soviet era Russia are sparse and anemic (Gilbert and Balzer 2012), while nostalgia about the socialist past has been growing (Rose 2009; White 2010). At first glance, all of this seems somewhat counterintuitive, especially to those who embraced the assumption that post-socialist societies were destined for democratization and ready and willing to efficiently absorb neoliberal ideas and models of Western economics and politics.

In order to understand the "unexpected" contemporary outcomes, some social scientists began to investigate the reasons for the divergence between anticipated and actual democratic developments by studying people's historical experiences - and the socialist past in particular - as sociocultural factors that continued to impact institutions, attitudes, and behavior after the Soviet era had ended. These factors were united under the umbrella concept of "communist legacies" which has become the dominant paradigm for explaining social, political, and economic outcomes in the post-socialist era. (For a more detailed discussion on this topic see LaPorte and Lussier (2011).)

One reason for the widespread acceptance of the communist legacies explanation for the state of Russia and other former Soviet countries today has been the empirical support this explanation supposedly has received from systematic research studies. Howard's $(2003,2011)$ extensive study of civil societies and the role of cultural legacies in post-socialist countries, for example, has been especially influential. Howard introduced a number of novel theoretical concepts and methodologies. His frequently cited research was the first attempt to demonstrate the continuity, over an extended period of time and radically changing situations, of people's attitudes and behavior in the sphere of civic activism. In Howard's research-based storyline, some culturally grounded attitudes and behaviors function as constraints on democratization, constraints that are, in essence, embedded in a country's socialist past.

In this article, I will first discuss the concept of communist legacy. Then I will describe how Howard $(2003,2011)$ provided empirical support for the notion that the communist legacy was a major explanatory variable in accounting for the supposed state of civil society in Russia today. Finally, I will critically examine the methods Howard used and the a priori assumptions he made to demonstrate that his research was not entirely empirical and that his findings and conclusions, therefore, cannot be taken as unequivocal proof of the communist legacy's negative impact on civil society in Russia and, presumably, other former Soviet countries, as well. 


\section{"Communist Legacies" as Explanatory Factors for Post-Socialist Development}

As has already been noted, the notion of "legacy" enjoys the status of an important explanatory in studies of post-socialist countries, including Russia. However, the "legacy paradigm" does not yet have a widely accepted definition, common concepts, and clearly articulated criteria, despite several recent attempts to summarize and analyze research built around the legacy construct (see, e.g. reviews of LaPorte and Lussier 2011; Pop-Eleches and Tucker 2011; Wittenberg 2012). Millar and Wolchik (1994) defined socialist legacies ${ }^{1}$ (or at least the cultural aspects of them) as "values, attitudes, and behavior of the population" whether instilled by the state or "developed as the result of living under a communist system" (10). ${ }^{2}$ Unfortunately, many other researchers, including Howard (2003), rarely explain in detail what they mean by legacies. At best, they note that the term refers to something that occurred in the past and, in one way or another, influences the present.

Undoubtedly, for many contemporary scholars, legacy thinking can be traced back to Jowitt's (1992) discussion of "the Leninist legacy" in his book New World Disorder: The Leninist Extinction. He predicted that new institutional patterns would be shaped by "the legacy of Leninist rule," i.e. "[the] fragmented, mutually suspicious, societies with little religious-cultural support for tolerant and individually self-reliant behavior" (304). Jowitt applied the term "Leninist legacy" as a general condition negatively impacting the political, economic, and social spheres in Russia and other post-socialist countries and painted socialist and post-socialist phenomena with wide brush strokes. Later social researchers found multiple legacies that vary in scope and intensity across different countries. In their detailed review of studies conducted during the previous 20 years, LaPorte and Lussier (2011) give examples of such legacies that have been cited by multiple scholars researching post-socialist society: "authoritarian collectivism, a free-lunch mentality, weak states, bloated bureaucracies, centralized economic planning, popular expectation of cradle-to-grave welfare, state

1 In this article, terms of "socialist legacies," “communist legacies," "Soviet legacies” are used interchangeably.

2 Compare the contemporary definition of “communist” legacies with Marx's (1875/1970) statement from the Critique of the Gotha Program: "early socialism...just as it emerges from capitalist society; which is thus in every respect, economically, morally, and intellectually, still stamped with the birthmarks of the old society from whose womb it emerges." 
monopoly over property, capricious leadership, ethnic identities, and informal networks of exchange" (640). ${ }^{3}$ LaPorte and Lussier characterize the typology of "communist legacies" along two dimensions: the domain (political, economic, social) in which the legacy is detected and the unit of operational analysis. As for the latter, they distinguish between institutional legacies within the whole society and legacies engendered in attitudes and behaviors on the individual and group levels. According to their typology, the institutional level is the broadest one and includes, e.g. the structure of a socialist state, the absence of state-independent representative organizations, the distribution of social services, and a low level of economic and social inequality laws $(646,648)$. The other units of analysis - attitudinal and behavioral - can be applied at the individual and group levels. An example would be mistrust of the political sphere or an individual's reliance on informal friendship networks to solve collective action and transaction problems (648).

The most challenging methodological problem for social researchers, however, appears when researchers attempt to provide evidence related to a causeeffect relationships between the perceived or assumed "legacies" and the current situation (LaPorte and Lussier 2011; Wittenberg 2012). Because of this, Howard's (2003) work must be considered exceptional, as he specifically focuses on providing evidence and argumentation to illuminate a casual effect of "communist legacies" on the current state of civil society in Russia as well as in other post-socialist countries.

\section{Empirical Support for the Cultural Legacy Explanation}

In 2003, Howard published the results of his research in his monograph The Weakness of Civil Society in Post-Communist Europe. He later reiterated the study results and his interpretation of their meaning, in a more abbreviated form, in a chapter "Civil Society in Post-Communist Europe" in The Oxford Handbook of Civil Society published in 2011. In both publications, and in the research that gave rise to them, Howard focused on the influence of attitudinal and behavioral "communist legacies" on the civic societies - i.e. citizens' engagement in associational life - of both Russia and the former East Germany after the collapse of communism and the socialist states in Eastern Europe. Howard used both

3 These examples, by the way, demonstrate that connotations related to "communist legacies" range from negative to neutral in contemporary research of institutional and cultural patterns associated with socialist past. 
quantitative survey data and qualitative interviews. His quantitatively based conclusion about the current weakness of civil society in the countries he studied was based on measurements of the number of organizational membership per person (NMP) in formal voluntary associations using comparative international data primarily from the World Value Survey (WVS) conducted in 1995-97. ${ }^{4}$ Regression analysis of data for several countries revealed that one of the variables, "prior communist experience," was by far the most powerful negative predictor of the strength of a country's civil society after the historical juncture (such as revolutions and dramatic changes in state ideology). ${ }^{5}$

Analysis of data from in-depth interviews with Russians and East Germans followed by a regional survey in Russia and the East and West Germany allowed Howard to provide experiential reasons "why people do or do not participate in voluntary organizations" $(2003,121)$. First, the researcher interpreted the data to identify and clarify the reasons respondents articulated during the interviews. Next, he broke down the "post-communist experience" into three variables: "mistrust of communist organizations," "the persistence of friendship networks," and "disappointment with post-communism." As Howard explained, the specific purpose for the survey, which followed interviews, was to demonstrate the relevance and importance of the three factors mentioned above (121). The researcher asked whether respondents from Russia and East Germany participated in both the "state-run communist organizations" before the reforms started in those former socialist states and in contemporary formal voluntary organizations, at present.

A second set of questions addressed respondents' participation in friendship networks and perceived changes in those networks from communist to contemporary times. Answers were grouped depending on whether respondent's use of personal networks had decreased over time or had persisted at former levels. A third group of questions required respondents to evaluate the changes of the past decade compared to their initial expectations. The analysis of the survey led Howard to conclude that:

(1) citizens with higher levels of mistrust in communist organizations tend to be less active in voluntary organizations today, (2) that people whose friendship networks have persisted

4 The WVS includes a question about membership in nine types of voluntary organizations: church and religious organization, sport and recreation organization, art, music, or educational organization, labor union, political party, environmental professional association, charitable organization, any other voluntary organization.

5 Howard confirmed those results by conducting his own survey in Russia and Eastern and Western parts of Germany in 1999. Survey results: $81 \%$ of West Germans belonged to at least one organization, only 52\% of East Germans and as little as 35\% of Russians did so (Howard 2003, 101). 
in the post-communist period are less likely to join organizations today, and (3) that the more disappointed people are with post-communist developments, the less likely they are to participate (92-93).

He characterized the first two conclusions as the "direct legacies from the communist past" (122). According to Howard, "communist legacies" stem from the fact that all civic activities and organizations during the communist rule were involuntary, were not a part of a valid civic society, and triggered mostly negative attitudes that impacted associational membership in the future. Howard asserted that people strongly retained attitudes and forms of behavior inherited from socialist times. He concluded that a total generational shift is required to bring the development of more active membership in formal voluntary organizations and that more active membership would only occur when a new demographic cohort enters the public sphere. He also suggested that the state should play a more active role in recruiting citizens into civic activities by cooperating with voluntary associations.

All of this was quite convincing to much of the research community in the West, ${ }^{6}$ as well as some researchers in Russia and other parts of Eastern Europe who were influenced by Western scholarship and embraced the paradigms and perspectives that framed a large amount of Western research (see, e.g. Evans 2006; Crotty 2009; Ljubownikow, Jo Crotty, and Rodgers 2013). Many social scientists, in fact, often reference Howard's findings in their own later research of post-socialist civil society, though they almost never discuss the methodological details of his work. ${ }^{7}$ Rather, his findings are simply treated as empirically supported facts. However, a closer look at Howard's study reveals a number of problems with the methods he employed and the assumptions he made in grounding his empirical work.

\section{Critique of Methods and Assumptions}

Empirical research is never entirely empirical. The empirical data that are generated and reported often reflect the framing and design of a particular study as much as the empirical world that was explored (see more in Kuhn

\footnotetext{
6 With a notable exception of researchers representing an anthropological approach (see more in Hann, Humphrey, and Verdery 2002)

7 See, e.g. Kubik 2005; Fioramonti and Heinrich 2007; Chebankova 2009; Crotty 2009; Jakobson and Sanovich 2010; Uhlin 2010; Ekiert and Foa 2011; Pop-eleches and Tucker 2011; Spencer 2011; Karakoc and Baskan 2012; LaPorte and Lussier 2011; Letki and Mierina 2012; Wallace, Pichler, and Haerpfer 2012; Ljubownikow, Crotty, and Rodgers 2013.
} 
1962/1996). This section takes a critical look at the methods and a priori assumptions that influenced Howard's $(2003,2011)$ findings about the impact of "communist legacies” on contemporary Russia.

\section{Conceptualization of Civil Society}

In his study, Howard uses a rather restrictive definition of a civil society. Like a number of other influential writers (see, e.g. de Tocqueville 1840/1988; Putnam, Leonardi, and Nanetti 1994; Skocpol 2004), he assumed that a vibrant civil society is based on active and voluntary associational life. For Howard, however, "civil society does not refer to simply any form of mobilization, but to membership and participation in a formally organized group, club, or association" (39, emphasis added). In short, for Howard, formal voluntary associations are the lynchpins of democratic development, and insufficient involvement in formally organized associational activities by citizens is seen as an impediment to the development of a democracy. Because of this emphasis on formal organizations, Howard did not pay attention to peoples' experiences in a wide variety of largely informal civic activities both in the past and present. Ironically, in some of the excerpts from interview transcriptions that Howard published, several Russian respondents emphasized their preference for participation in voluntary activities that did not occur in formal organizational settings (138-139). ${ }^{8}$ These data, however, were not employed in the communist legacy storyline that Howard developed.

The institutional structure and normative base of a civil society, in fact, is a subject of considerable debate. Debates have focused on a number of questions: Does the concept encompass organizational elements such as political parties, social movements, and informal social activities and structures or not? How does one differentiate between civic and noncivic organizations? ${ }^{9}$ Howard was aware of these debates and presented counter arguments to a wide range of theoretical models of civil society found in contemporary scholarship (see, e.g. Edwards 2011b) that differ from his own.

The point that matters here, however, is that research findings and conclusions almost certainly will be different depending on which conception of civil society one ${ }^{10}$ employs. As Ekiert and Foa (2011) have noted,

8 This trend was supported by the survey data presented by Yakobson et al. (2011, 22).

9 See more in The Oxford Handbook of Civil Society (Edwards 2011), especially Bob's chapter (2011) on civil and uncivil society.

10 A discussion of the contemporary situation in Russia and other post-socialist countries is beyond the scope of this article. The methodology of analysis of civic practices and assessing 
If we pursue a multidimensional strategy for analyzing the constitution of civil society and civic behavior - that is, by measuring organization and behavior of civil society actors along a range of different dimensions and using a range of different sources rather than by a single concept or instrument - the picture of post-communist civil society becomes more complex and more interesting (38).

In short, limiting the definition (and measurement) of civil society to involvement in formal organizations may be helpful in promoting Howard's conclusion that communist legacies (in Howard's work, attitudinal and behavioral legacies) are the source of the current state of affairs in Russia and other former Soviet countries. Such a move, however, virtually guarantees that much of the complexity of civic life will be obscured and that the supposedly empirically grounded stories Howard and like-minded scholars tells about the post-Soviet era and its impact will be, at best, incomplete and, at worst, largely fictional. These stories, in other words, reflect the a priori assumptions and operational definitions employed at least as much as - and possibly more than - the actual empirical reality researchers like Howard are ostensibly trying to describe and explain.

\section{An Inappropriately Bleak Picture of the Civil Society in the Soviet Past}

The second problem with Howard's supposedly empirical analysis is actually shared by much of Western political science, the discipline that socialized Howard and many other Western (and even some Eastern) social scientists. This problem involves the overwhelmingly negative a priori characterizations of the old Soviet Union (and socialist regimes, in general), characterizations that continue to influence the language and variables employed in studies of the Soviet past and present. ${ }^{11}$ This approach can partly explain why some Western social scientists, including Howard, are unaware of certain social and civic practices in the past or, at least, why they seem to discount even the possibility that cultural legacies from the Soviet era might have a positive impact on the present. $^{12}$

the vitality of the post-socialist civil society by focusing excessively on voluntary membership and survey data has been criticized from different perspectives (e.g. Hann, Humphrey, and Verdery 2002; Ekiert and Foa 2011).

11 For a somewhat more balanced analysis of the civic activities in the Soviet Russia, see Evans 2006.

12 For an alternative methodological approach, and consequently, opposite conclusions, see, e. g. ethnographic research conducted by Henry (2006), White (2006), and Kulmala (2013). 
The attitudes are at least somewhat understandable. They emerged from a time of Cold War confrontation, a time when the world was, in many people's minds, divided into heroes and villains and between those who were intent on making the world safe for democratic participation and a civil society that supported democracy, on the one hand, and those who presumably embraced antithetical goals, on the other. According to several analysts, this thinking has impacted basic theoretical assumptions methodology in research of post-socialist realm (e.g. Creed and Wedel 1997; Hann, Humphrey, and Verdery 2002; Mandel 2012). In the context of civil society research, the paradigm was that (a) "everything created prior to the collapse of communism was... 'not a true civil society" and/or (b) post-socialist development was "contaminated and adulterated by the Communist legacy... [and] had to be purged before any "true civil society' and democracy could flourish” (Ishkanian 2007, 69).

During the last two decades, such perceptions have impacted the design and implementation of Western government policies in the area of democracy promotion in the post-socialist countries (e.g. Creed and Wedel 1997; Hemment 2004; Henderson 2002; Mandel 2002; Ishkanian 2007; Matveeva 2008). And, of course, these perceptions also influenced researchers, but, of course, not all researchers. In his review of contemporary sociohistorical studies of the civil society in East European countries, for example, Valkov (2009) noticed that research outcomes ranged "from complete denial of associational activities in the past to the discovery of persistent civic engagement across time" (428).

Howard appears to be closer to the denial end of the continuum suggested by Valkov's (2009) review. He relied mostly on statements made by Jowitt (1992) and Bunce (1999) that characterized all associations in the socialist countries, including Soviet Russia, as being “communist," i.e. entirely organized, sponsored, and controlled by the single-party state. ${ }^{13}$ Despite admitting a high organizational density of membership associations in socialist countries, Howard did not recognize them as being voluntary and/or independent. Additionally, as has already been noted, Howard did not give any credit for participation in informal collective grassroot activities. Consequently, he ignored the most intensive period of the social movements and various civic initiatives that emerged in the USSR in the end of the 1980s. He also did not take note of

13 The list includes political parties, religious organizations, trade unions, sport, and art associations, etc. - Howard (2003, 106); see also description of his survey questionnaire on pp. 170-74. His conclusions about the civil society assumed that political parties were part of the civil society. It might be against common perceptions among his Russian respondents and believes of some of his colleagues who usually associate political parties not with the civil society but with the state (e.g. Henry and Sundstrom 2006). 
other periods in the history of Russia and, to some extent, the Soviet Union, generally, when associational life flourished: in the 1920s (during the New Economic Policy), the 1960s (during the Khrushchev Thaw), and from 1986 to 1992 (immediately before the collapse of the Soviet Union). (See more about what was going on during these periods in Mersiyanova (2000), Haliy (2007), and Jakobson and Sanvich (2010). $)^{14}$

In short, because of what it ignored, Howard's research, by design, could not provide data about any positive associational experiences in his respondents' social lives. Rather, his research was explicitly designed to focus exclusively on non-participation in formal organizations. This design feature was undoubtedly more unconscious than conscious and, clearly, reflected the legacy of Cold War thinking in the West, as well as a certain conception of civil society that equates civil society with the involvement of citizens in formal organizations. As the next section of this paper will indicate, however, the legacy of informal associational activity is very much a part of the history of Russia, at least.

Thus, Howard's conclusions that the civil society in the Soviet Russia and Eastern European socialist countries, in general, has been virtually non-existent (and certainly not vibrant) after the demise of the Soviet Union is quite problematic. At the very least, it is a conclusion that is not primarily empirical but, rather, reflects the decisions that were made prior to the collection of empirical data. At any rate, Howard's conviction about the absence of a "normatively" civic life in the Soviet past (unsupported by any articulated or referenced evidence, it should be noted) becomes an explanation for Russians' present civic attitudes and behavior.

\section{Differing Perspectives of the Role of Informal Networks in Russia's Civil Society}

A third critique of Howard's work, as well as the work of the many scholars who have uncritically accepted and extended Howard's analysis, involves Howard's

14 For instance, see Jeffrey Hanh (1988) - on citizens' grassroots activities on the local level in 1980s; Gerald Creed and Janine Wedel (1997) - on unconventional political activities in Russia during Brezhnev times; Sarah Ashwin (1999) - on the social and civic role of membership in trade union of coal miners before and after reforms in Russian province; Melissa Caldwell (2004) - on the role of informal social connections for joint activities in charity work of ordinary Muscovites; Meri Kulmala (2013) - on "socialist” skills and resources successfully applied by activist in small town settings. See also a collection of correspondent findings in Evans, Henry, and Sundstrom (2006). See also detailed review of Russian and international scholars publications on that matter in Evans (2006). 
lack of sensitivity to Russian culture. ${ }^{15}$ As was mentioned in the previous section, several interviewees in Howard's study demonstrated their preferences for informal engagement, volunteering, and philanthropic actions (see more Howard 2003, 138-139). This is hardly surprising because, in Russia, there is a tradition of civic and social engagement through wide and comprehensive informal networks.

Howard is clearly aware of these informal networks; however, he dismisses them as tiny, but persistent, friendship and kinship networks that are the direct legacy of the socialist past (122). Howard actually asserts that these networks have had a negative impact on the development of the civil society because they prevent participants from joining formal voluntary organizations. This position is problematic for a number of reasons.

First, there is no justification for assigning this friendship/kinship network legacy to communist times. The role of membership in kollektiv (defined as a kind of extensive informal network within or beyond official organizations) can be traced back deep into Russian societal history (see, e.g. Ely 2009; Lindenmeyr 2011; Spencer 2011). Several scholars have emphasized the cultural specifics of Russian communitarian life, which includes traditions of social cooperation mostly in informal institutional settings across centuries (e.g. Kharkhordin 1998; Alapuro and Lonkila 2000; Spencer 2011; Bremer 2012). These traditions persisted over many generations and still influence preferences and practices of the collective voluntary work in Russia beyond formal organizational settings (see more in Ely 2009; Lindenmeyr 2011; Spencer 2011).

Second, friendship networks historically have not only been widespread in Russia but also were more multifunctional (e.g. Kasyanova 1994; Kharkhordin 1998) than the particularistic and pragmatic friendship networks in Anglo-Saxon culture (see more about this in Stewart and Bennett 1991). Interestingly, however, if we look beyond the proliferation of small networks of immediate family members and close friends, which were the only safety net left after the economic collapse of socialist countries, Howard's (2003) interview data actually suggest a rather dramatic decline in respondent's use of the traditional broader informal networks in the post-socialist countries. Answering questions about changes in the interpersonal relations after the reforms, respondents from both Russia and East Germany emphasized the following common themes: "the increased focus on personal life, the newly prominent and destructive role of money, far greater social inequality, and the transformation of the work environment" (135). Many respondents expressed nostalgia for the sense of

15 There may also be a misunderstanding of other cultures of the countries that made up the USSR, as well, but that discussion is beyond the scope of this paper. 
community they enjoyed before - e.g. the supportive network of work collectives, the spiritual closeness with people other than their immediate family members - which they perceived as having gone away, along with the socialist past.

For the majority of Howard's interviewees, then, the post-socialist period brought painful experiences of the demolition of their earlier wider networks of kollectivs, which included former colleagues and classmates. Most likely, this destruction of the "civic habitat" has, indeed, inhibited civic development in the post-Soviet era, as Howard claims. However, traditional friendship networks and the ongoing changes within them impacted civic activities of Russians, including their involvement in associational life in decidedly different ways than the ways described by Howard. ${ }^{16}$

To summarize, the key points in this section are as follows: (a) Informal networks are a pre-socialist cultural legacy, at least in Russia. (b) They operated effectively during the socialist era within and beyond pragmatic functions. (c) Rather than functioning as inhibitors of the development of civil society in postSoviet Russia, their intensity and possible influence has actually declined. (d) Such networks have their own dynamics and appear to have an ambiguous impact on the forms and intensity of citizens' engagement in civic life, especially if the impact of social media is considered.

Howard and other scholar who have uncritically accepted Howard's empirical findings and interpretations have missed most of this, despite the fact that Howard's interview data points out the significance of at least some of these points. Of course, there is no reason to assume that an insider's view of a culture (what anthropologists characterize an emic perspective) is necessarily superior to the views of outsiders. At the very least, however, the emic perspective of Russia's cultural history is a reminder that Howard's communist-legacy storyline was shaped by his own priori cultural perspectives and not simply by the empirical data he gathered.

16 Recent research on the role of extensive informal networks in Russia suggests that these cultural traditions can have both negative and positive effect on development of civic activism (Ledeneva 2013), especially in times of widespread use of Internet technology. Ledeneva, for instance, has argued that social networking sites were more effective in channeling protest movements than traditional forms of oppositional activism (see also on the role of social media blogs in Russia in Bode and Makarychev (2013). Additionally, informal connectedness on the regional and local levels could be considered as an important prerequisite for new forms of active civic engagement to emerge beyond formal associational life (e.g. White 2006; Kulmala 2013). 


\section{Interpretation of the Survey and Interview Data}

A final problem with Howard's analysis is primarily methodological. Howard's (2003) bottom-line argument is that having had an "essentially negative experience with state-run organizations during the communist period, the majority of citizens throughout post-communist Europe continue to have a common sense of mistrust of organizations today" (140, italics added). This conclusion of his study has been accepted uncritically by many scholars. However, there are clearly problems with the way Howard operationalized and measured mistrust. Howard was measuring "mistrust of communist organizations by the extent to which [people] avoided joining organizations in the communist period" (107, emphasis added). Howard elaborated:

The category of "low" mistrust applies to those who were members of 4-9 communist organizations, "medium" mistrust to those who belonged to 3 communist organizations, and "high" mistrust to those who were members of only $0-2$ communist organizations (note on 107).

According to this logic, those who had never been a member of any formal organization in the past had the most negative experience of associational life. Conversely, those who were members of many organizations were characterized as "having positive experiences, or low mistrust of communist organizations (127).”

If we disregard the "communist" affiliation that Howard bestows on all organizations during the Soviet times, his conclusion is a virtual truism: the more organizational memberships a person has had in the past, the more likely he or she is to participate in voluntary organizations at present. This truism, however, presents a problem for Howard (see more in Letki 2004). Howard underlined that numerous membership organizations existed during socialist times. If we assume that the number of participants in those "communist organizations" was also high, by definition (i.e. Howard's definition), the number of people with "positive experiences" in membership organizations during socialism should also be high. However, this contradicts Howard's major conclusion that was discussed above. i.e., that post-Soviet avoidance of membership in formal voluntary organizations today is the result of individuals' negative experiences with organizational practices during the socialist era.

There is a possible way out of this contradiction, of course; Howard can simply claim that involvement in voluntary associations during the Soviet era was not really voluntary. This claim, however, calls into question Howard's assumption that those who were members of many organizations were "having positive experiences, or low mistrust of communist organizations” (127). 
Even more problematic for Howard's storyline is the failure of Howard's interview data to support the claims he makes about the impact of the communist legacy. As Howard, himself, admits, Russian interviewees, unlike East Germans, normally did not refer to their communist past experiences in explaining their current civic non-participation. For example, even people currently avoiding membership in official organizations in Russia do not express extreme or hostile attitudes to all membership associations in the past (though one did mentioned antipathy toward rigid organizational obligations under socialism (126)). Most Russian interviewees described a more general view of organizations as "unnecessary, useless, and sometimes distasteful" (127) and explained their own passiveness being caused by work pressure, lack of free time, or other personal interests.

Thus, claims that the phenomenon of mistrust of civic organizations is a product of the socialist past are not supported by Howard's own cross-national interview data in all cases, especially the case of Russia. The finding that majority of citizens in post-socialist countries avoid joining the membership associations because of a negative attitude to those organizations during socialist period is, at best, an overgeneralization.

\section{Conclusion and the Search for Alternatives}

Howard (2003, 2011) was the first scholar who focused on the cultural aspects of historical legacies at the individual level by studying peoples' individual perceptions and experiences in post-socialist countries. He claimed to have found continuity across the Soviet and post-Soviet eras in terms of the several attitudinal and behavior patterns (such as "mistrust of communist organizations," "the persistence of friendship networks") and defined the patterns he identified as the "communist legacies." The researcher also postulated that these legacies were the major inhibiting factors in citizens joining formal membership associations that some scholars consider to be a cornerstone of viable and vibrant civil societies in Western countries. Finally, he concluded that a generational shift may be required for development of a "real" civil society in post-socialist countries (Howard 2003, 146, 155-160). ${ }^{17}$

17 Ironically, the discourse of negative "vestiges of the past" and recommendations of how to get rid of them was first introduced to explain the drawbacks in societal practices by communist classics. In the Soviet Russia, phrases like "birthmarks of capitalism" and "remnants of capitalism" were a part of the discourse of Soviet indoctrination for 70 years and later acquired satiric connotations among ordinary people who were losing faith in the official propaganda. 
Howard's study has been, arguably, the most cited and influential one in the field. Among other contributions, it directed the scholarly community's attention to the importance of studying civil society development from the perspective of an ordinary person and, also, to the impact of generational characteristics on individuals' civic attitudes and behavior. All of this is laudable. However, there are also problems with a number of Howard's a priori assumptions and with the empirical work that was framed by these assumptions and that influenced Howard's “empirical” findings. This article critiqued Howard's seminal thinking and research that, to date, has been accepted relatively uncritically.

The questions that have been left unanswered, of course, are: What are some alternatives to what Howard has done? Why is it important to consider alternative approaches? Adequately answering these questions would require more space than is available in the conclusion of the current paper. I will, however, attempt to sketch out four answers to the first question that are implicit in the critique presented above and, also, say a bit about why alternatives are needed.

\section{Four Alternatives}

First, it is important that researchers stop painting with broad brushstrokes and focus, instead, on the unique cultural aspects of each of the former socialist countries. Howard, himself, acknowledged that his data suggested there were differences between Russia and East Germany, but this insight was lost by the time Howard articulated the conclusions of his study. Presumably, this loss occurred, at least in part, because Howard was not particularly interested in the unique features of each country. This is unfortunate because, even when countries have similar ideologies and similar official state policies, there is not necessarily uniformity in perspectives and actions at the individual and local community levels. On the other hand, Yurchak (2006) has written in the case of Russia,

[It] is the crucial and seemingly paradoxical fact that, for great numbers of Soviet citizens, many of the fundamental values, ideals, and realities of socialist life (such as equality, community, selflessness, altruism, friendship, ethical relations, safety, education, work, creativity, and concern for the future) were of genuine importance, despite the fact that many of their everyday practices routinely transgressed, reinterpreted, or refused certain norms and rules represented in the official ideology of the socialist state. For many, "socialism" as a system of human values and as an everyday reality of "normal life" (normal'naia zhizn') was not necessarily equivalent to "the state" or "ideology"; indeed, living socialism to them often meant something quite different from the official interpretations provided by state rhetoric (8). 
Second, to understand the different ways citizens in different countries made sense of official ideology and state policy, there is a need for historical research that documents the defining elements of a country's culture prior to the socialist era. A country's culture and various social practices embedded in it, after all, did not begin with the socialist period. Rather cultures already existed in each of the countries that became part of the socialist bloc. These cultures undoubtedly not only influenced how socialist era ideology and state policies impacted day-to-day life during the socialist era; they also continue to influence - the current era. ${ }^{18}$

A third implication for researchers of the critique that has been presented here is that researchers should recognize that they are also products of the cultures that have socialized them and that, consequently, they will inevitably be victims of epistemological ethnocentrism (Reagan 2005). This sort of ethnocentrism is, arguably, most evident in the scholarly community's uncritical embrace of Western liberal democracy as the societal model that Russia and other post-socialist countries should emulate. It is interesting that a social democratic model was almost never discussed as an option for Russia or other post-socialist countries (Alapuro 2008), even though there might have been greater continuity between past and present if this model had been employed (Kulmala 2013).

All researchers are inevitably victims of epistemological ethnocentrism, of course. Consequently, the only antidote is to insure that a range of models is employed to conceptualize everything from a country's ideal future state to the research methods used to study a country's past.

Fourth, in the study of civil society, it is not just all encompassing models that matter; the definitions we use within the models we employ also can be exceedingly important. Implicit in the critique presented in this paper, for example, is the need to expand the definition of civil society beyond membership in formal organizations and focus, as well, on citizen's engagement in informal groups and activities. As was noted in this paper, a preference for this sort of informal activity predates the socialist era in Russia, so it is impossible to really understand the extent of civil society in Russia, at least, if the aspects of informal civic life are ignored. Focusing on informal as well as formal

18 Several examples of Russian cultural practices, both formal and informal, have been already identified and may be used for further research of embedded cultural patterns of social and civic actions in Russia, such as obshchina - rural commune with normative functions, druzhina voluntary collective for providing urgent services (Alapuro and Lonkila 2000; Spencer 2011), subbotniki in socialist urban settings (Mersiyanova 2000; Jakobson and Sanvich 2010), and specifics of communal principles of Russian Orthodox Church and functioning of its congregations (see more in Kharkhordin 1998; White and McAllister 2000). 
civil society organizations also is essential for understanding the cultural aspects of civic activity in Russia and its dynamics over time, as well as the interaction of the formal and informal dimensions of civic life.

\section{Why Does This Matter?}

I will conclude this paper by briefly addressing what could be referred to as two "so-what" questions: Why does it matter that research tradition that can be traced back to Howard provides, at best, an incomplete and, at worst, a highly inaccurate picture of what has happened in Russia? Why should additional research employing different models and different definitions of the notion of civil society in Russia (and other countries) be undertaken?

Scholars, of course, are unlikely to need reasons to continue to explore social phenomena in new and different ways. For them, new knowledge is its own reward. Funders and policymakers, however, often are a bit more pragmatic. So, it is worth asking, what are the pragmatic reasons for moving beyond the research community's conventional explanations for what has happened in Russia during the post-socialist era, on the one hand, and engaging in different forms of research with new models and a different definition of civil society, on the other.

One rather obvious reason for trying to move beyond Howard's thinking and research is the bottom-line conclusion to which they lead: Significant change will occur in Russia only after generational change. This is a long time to wait; plus, even if we wait, there is no guarantee that a new generation socialized by the current generation will think and behave differently. And, of course, while we wait, there is no reason to develop policies and procedures designed to enhance civil society. Current thinking, in short, is a recipe for inaction.

By contrast, other ways of thinking that employ different models, different definitions, and different starting assumptions suggest greater possibilities for action, possibilities that are rooted in a more multifaceted view of the past and the assumptions that there are elements in Russia's "usable past" within the socialist legacy (Henry 2006, 224), that can be employed to develop civic activities (see also White 2006; Kulmala 2013). From this perspective, a significant part of accumulated experience of "socialist" and "pre-socialist" generations of the Russian society can be perceived as a potentially positive cultural heritage, rather than largely negative "vestiges of the past." This approach will promote inter-generational cooperation as a part of implementation of the research findings instead of requiring a generational shift. 
Acknowledgments: The author wishes to thank the anonymous reviewers of Nonprofit Policy Forum for their detailed comments. The author is deeply grateful to Mary McDonald, Robert Donmoyer, Elaine Lewis, and Michael Levin.

\section{References}

Alapuro, R., and M. Lonkila. 2000. "Networks, Identity and (In)Action." European Societies 2 (1): 65-90. doi:10.1080/146166900360738.

Alapuro, R. 2008. "Russian and Estonian Civil Society Compared." In Media, Culture and Society in Putin's Russia, edited by S. White, 72-91. Hampshire: Palgrave Macmillan.

Ashwin, S. 1999. Russian Workers: The Anatomy of Patience. Manchester: Manchester University Press.

Bob, C. 2011. "Civil and Uncivil Society." In The Oxford Handbook of Civil Society, edited by M. Edwards, 209-19. Oxford: Oxford University Press.

Bode, N., and A. Makarychev. 2013. "The New Social Media in Russia: Political Blogging by the Government and the Opposition." Problems of Post-Communism 60 (2): 53-62. doi:10.2753/PPC1075-8216600205.

Bremer, T. 2012. "Religion." In Routledge Handbook of Russian Politics and Society, edited by G. Gill and J. Young, 397-406. New York and London: Routledge.

Bunce, V. 1999. Subversive Institutions: The Design and the Destruction of Socialism and the State. Cambridge: Cambridge University Press.

Caldwell, M. L. 2004. Not by Bread Alone: Social Support in the New Russia. Berkeley, CA: University of California Press.

Carothers, T. 2002. “The End of the Transition Paradigm." Journal of Democracy 13 (1): 5-21. doi: $10.1353 /$ jod.2002.0003.

Chebankova, E. 2009 “The Evolution of Russia's Civil Society under Vladimir Putin: A Cause for Concern or Grounds for Optimism?” Perspectives on European Politics and Society 10 (3): 394-415. doi:10.1080/15705850903105819.

Creed, G. W., and J. R. Wedel. 1997. "Second Thoughts from the Second World: Interpreting Aid in Post-Communist Eastern Europe." Human Organizations 56 (3): 253-64. doi:001 87259/97/030253-12.

Crotty, Jo. 2009. "Making a Difference? NGOs and Civil Society Development in Russia." Europe-Asia Studies 61 (1): 85-108. doi: 10.1080/09668130802532936.

De Tocqueville, A. 1840/1988. Democracy in America. New York: Harper Perennial. Translated by George Lawrence and J. Mayer and edited by J. Mayer. Accessed December 3, 2013. http://xroads.virginia.edu/ HYPER/DETOC/toc_indx.html19.

Edwards, M., ed. 2011. The Oxford Handbook of Civil Society. Oxford: Oxford University Press.

Ekiert, G., and R. Foa. 2011. "Civil Society Weakness in Post-Communist Europe: A Preliminary Assessment.” Carlo Alberto Notebooks 198. Accessed November 12, 2013. http://www.carloalberto.org/working_papers.

Ely, C. 2009. "The Question of Civil Society in Late Imperial Russia." In A Companion to Russian History, vol.10, edited by A. Gleason, 225-42. Oxford: Wiley-Blackwell.

Evans, A. B. 2006. "Civil Society in the Soviet Union?" In Russian Civil Society: A Critical Assessment, edited by Alfred B. Evans Jr., Laura A. Henry, and Lisa McIntosh Sundstrom, 28-55. Armonk, NY: M. E. Sharpe. 
Evans, A. B., L. A. Henry, and L. M. Sundstrom, eds. 2006. Russian Civil Society: A Critical Assessment. Armonk, NY: M. E. Sharpe.

Evans, A. B. 2011. "The Failure of Democratization in Russia: A Comparative Perspective." Journal of Eurasian Studies 2 (1): 40-51. doi:10.1016/j.euras.2010.10.001.

Fioramonti, L., and V. Finn Heinrich. 2007. "How Civil Society Influences Policy : A Comparative Analysis of the CIVICUS Civil Society Index in Post-Communist Europe." CIVICUS/ODI Research Report commissioned by Research and Policy in Development (RAPID), Overseas Development Institute (ODI). Accessed November 12, 2013 at https://www.scribd.com/doc/52580316.

Gilbert, L., and H. Balzer. 2012. "Civil Society." In Routledge Handbook of Russian Politics and Society, 364-74. edited by G. Gill and J. Young: New York and London: Routledge.

Haliy, I. A. 2007. Sovremennye Obshchestvennye Dvizheniia: Innovatsionnyi Potentsial Rossiiskikh Preobrazovanii v Traditsionalistskoi Srede. [Халий И. А.] [Contemporary Social Movements: Innovative Potential of the Russian Transformations in the Traditionalist Environment, in Russian]. Moscow: Institute of Sociology, Russian Academy of Science. Accessed November 30, 2013. http://www.civisbook.ru/files/File/Halyi_2007_sovr.pdf.

Hanh, J. W. 1988. Soviet Grassroots: Citizens Participation in Local Soviet Government. Princeton, NJ: Princeton University Press.

Hann, C. M., C. Humphrey, and K. Verdery. 2002. "Introduction: Postsocialism as a Topic of Anthropological Investigation." In Postsocialism: Ideals, Ideologies and Practices in Eurasia, edited by C. Hann, C. Humphrey, and K. Verdery, 1-28. London: Routledge.

Hemment, J. 2004. "The Riddle of the Third Sector: Civil Society, International Aid, and NGOs in Russia." Anthropological Quarterly 77 (2): 215-41. doi:10.1353/anq.2004.0069. 20.

Henderson, S. L. 2002. "Selling Civil Society: Western Aid and the Nongovernmental Organization Sector in Russia." Comparative Political Studies 35 (2): 139-67. doi: 10.1177/ 0010414002035002001.

Henry, L. A. 2006. "Russian Environmentalists and Civil Society." In Russian Civil Society: A Critical Assessment, edited by E. Jr. Alfred B., L. A. Henry, and L. M. Sundstrom, 211-28. Armonk, NY: M. E. Sharpe.

Henry, L. A., and L. M. Sundstrom. 2006. "Introduction." In Russian Civil Society: A Critical Assessment, edited by E. Jr. Alfred B., L. A. Henry, and L. M. Sundstrom, 1-30. Armonk, NY: M. E. Sharpe.

Howard, M. M. 2003. The Weakness of Civil Society in Post-Communist Europe. Cambridge: Cambridge University Press.

Howard, M. M. 2011. "Civil Society in Post-Communist Europe." In The Oxford Handbook of Civil Society, edited by M. Edwards, 134-45. Oxford: Oxford University Press.

Ishkanian, A. 2007. "Democracy Promotion and Civil Society." In Global Civil Society 2007/8: Communicative Power and Democracy, edited by M. Albrow, H. K. Anheier, M. Glasius, M. Kaldor, and Monroe E. Price, 58-85. London: Sage. Accessed September 20, 2013. http://www.gcsknowledgebase.org.

Jakobson, L., and S. Sanovich. 2010. "The Changing Models of the Russian Third Sector: Import Substitution Phase.” Journal of Civil Society 6 (3): 279-300. doi:10.1080/ 17448689.2010.528951.

Jowitt, K. 1992. The New World Disorder: The Leninist Extinction. Berkeley and Los Angeles, CA: University of California Press. 
Karakoc, E., and B. Baskan. 2012. "Religion in Politics: How Does Inequality Affect Public Secularization?” Comparative Political Studies 45 (12): 1510-41. doi:10.1177/0010414012453027.

Kasyanova, K. 1994. O Russkom Natsional'nom Kharaktere. Moscow: Institute on National Economic Model. Accessed June 10, 2014 . http://www.etnosy.ru/node/502 (Russian National Character, in Russian).

Kharkhordin, O. 1998. "First Europe-Asia Lecture: Civil Society and Orthodox Christianity." Europe-Asia Studies 50 (6): 949-68. doi:10.1080/09668139808412576.

Kubik, J. 2005. "How to Study Civil Society: The State of the Art and What to Do Next." East European Politics and Societies 19 (1): 105-20. doi:10.1177/0888325404272556.

Kuhn, T. S. 1962/1996. The Structure of Scientific Revolutions, 3rd ed. Chicago: University of Chicago Press.

Kulmala, M. 2013. "State and Society in Small-Town Russia. A Feminist-Ethnographic Inquiry into the Boundaries of Society in the Finnish-Russian Boundaryland.” Academic Dissertation. Department of Social Research 2013:14. Helsinki, Finland: University of Helsinki.

LaPorte, J., and D. N. Lussier. 2011. "What Is the Leninist Legacy? Assessing Twenty Years of Scholarship." Slavic Review 70 (3): 637-54. Accessed November 13, 2013. http://www. jstor.org/stable/10.5612/slavicreview.70.3.0637.

Ledeneva, A. V. 2013. Can Russia Modernise?: Sistema, Power Networks and Informal Governance. Cambridge: Cambridge University Press.

Letki, N. 2004. "Socialization for Participation? Trust, Membership, and Democratization in East-Central Europe.” Political Research Quarterly 57 (4): 665-79. Accessed November 16, 2013. http://www.jstor.org/stable/3219827.

Letki, N., and I. Mierina. 2012. "The Power of Networks. Individual and Contextual Determinants of Mobilising Social Networks for Help." AIAS, GINI Discussion Paper 45. Accessed May 14, 2014. http://www.gini-research.org.

Lindenmeyr, A. 2011. “'Primordial and Gelatinous'?: Civil Society in Imperial Russia.” Kritika: Explorations in Russian and Eurasian History 12 (3): 705-20. doi:10.1353/kri.2011.0039.

Ljubownikow, S., J. Jo Crotty, and P. W. Rodgers. 2013. "The State and Civil Society in PostSoviet Russia: The Development of a Russian-Style Civil Society." Progress in Development Studies 13 (2): 153-66. doi:10.1177/1464993412466507.

Mandel, R. 2002. "Seeding Civil Society." In Postsocialism: Ideals, Ideologies and Practices in Eurasia, edited by C. Hann, 279-96. London: Routledge.

Mandel, R. 2012. “Introduction: Transition to Where? Developing Post-Soviet Space." Slavic Review 71 (2): 223-33. Accessed January 20, 2014. http://www.jstor.org/stable/10.5612/ slavicreview.71.2.0223.

Marx, K. (1875). 1970. "Critique of the Gotha Programme." In Marx/Engels Selected Works 3: 13-30. Moscow: Progress Publishers. Accessed February 12, 2015. https://www.marxists.org/archive/marx/works/1875/gotha/ch01.htm

Matveeva, A. 2008. "Exporting Civil Society: The Post-Communist Experience.” Problems of Post-Communism 55 (2): 3-13. doi:10.2753/PPC1075-8216550201.

Mersiyanova, I. V. 2000. "Stanovlenie Negosudarstvennyh Nekommercheskih Organizacii kak Rezul'tat Samoorganizatsii Naselenija” [Formation of Non-government Non-profit Organizations as a Result of Self-organization of Population, in Russian]. In Perspektivy Samoupravleniia i Samoorganizatsii v Rossii, edited by I. A. Butenko, 57-78. Moscow. Accessed June 20, 2013. Accessed November 22, 2013. www.pravo.vuzlib.org/ book_z368_page_10.html. 
Millar, J. R., and S. L. Wolchik. 1994. "Introduction: The Social Legacies and the Aftermath of Communism." In The Social Legacy of Communism, edited by J. R. Millar and S. L. Wolchik, 1-30. Cambridge: Cambridge University Press.

Pop-eleches, G., and J. A. Tucker. 2011. “Communism's Shadow: Post-Communist Legacies, Values, and Behavior." Comparative Politics 43 (4): 379-408. Accessed November 7, 2013. https://files.nyu.edu/jat7/public/Ref_Journal_Article_CP_Pop-Eleches_Tucker_2010.pdf.

Putnam, R. D., R. Leonardi, and R. Y. Nanetti. 1994. Making Democracy Work: Civic Traditions in Modern Italy. Princeton, NJ: Princeton University Press.

Reagan, T. 2005. Non-Western Educational Traditions: Indigenous Approaches to Educational Thought and Practice, 3rd ed. Mahwah, NJ: Lawrence Erlbaum Associates.

Rose, R. 2009. Understanding Post-Communist Transformation: A Bottom Up Approach. New York: Routledge.

Sakwa, R. 2012. "Democratization." In Routledge Handbook of Russian Politics and Society, edited by G. Gill and J. Young, 33-44. New York and London: Routledge.

Skocpol, T. 2004. Diminished Democracy: From Membership to Management in American Civic Life. Julian J. Rothbaum Distinguished Lecture Series. Norman, OK: University of Oklahoma Press.

Spencer, S. B. 2011. "Culture as Structure in Emerging Civic Organizations in Russia." Nonprofit and Voluntary Sector Quarterly 40 (6): 1073-91. doi:10.1177/0899764010384140.

Stewart, E. C., and M. J. Bennett. 1991. American Cultural Patterns: A Cross-Cultural Perspective. Yarmouth, ME: Intercultural Press Inc.

Valkov, N. 2009. "Associational Culture in Pre-Communist Bulgaria: Considerations for Civil Society and Social Capital." Voluntas: International Journal of Voluntary and Nonprofit Organizations 20 (4): 424-47. doi:10.1007/s11266-009-9093-0.

Uhlin, A. 2010. "The Structure and Culture of Post-Communist Civil Society in Latvia." Europe-Asia Studies 62 (5): 829-52. doi:10.1080/09668136.2010.481388.

Wallace, C., F. Pichler, and C. Haerpfer. 2012. "Changing Patterns of Civil Society in Europe and America 1995-2005: Is Eastern Europe Different?” East European Politics \& Societies 26 (1): 3-19. doi:10.1177/0888325411401380.

White, A. 2006. “Is Civil Society Stronger in Small Towns?" In Russian Civil Society: A Critical Assessment, edited by A. B. Evans Jr., L. A. Henry, and L. M. Sundstrom, 284-301. Armonk, NY: M. E. Sharpe.

White, S., and I. McAllister. 2000. "Orthodoxy and Political Behavior in Post-Communist Russia." Review of Religious Research 41: 359-73. http://www.jstor.org/stable/3512035.

White, S. 2010. "Soviet Nostalgia and Russian Politics." Journal of Eurasian Studies 1 (1): 1-9. doi:10.1016/j.euras.2009.11.003.

Wittenberg, J. 2012. "What Is a Historical Legacy?" In Paper presented at the 19th International Council of Europeanists, Boston, MA, March 22-24, 2012. Berkeley: Department of Political Science, University of California. Accessed November 5, 2013. http:/witty.berkeley.edu/ Legacies.pdf.

Yakobson, L., I. Mersiyanova, O. Kononykhina, V. Benevolenski, E. Pamfilova, L. Proskuryakova, and A. Tumanova. 2011. Civil Society in Modernizing Russia [Electronic resource]: Analytical report prepared by the Centre for Studies of Civil Society and the Non-Profit Sector of the National Research University "Higher School of Economics". CIVICUS - World Alliance for Citizen Participation. Accessed November 11, 2013. https://www.civicus.org/ images/stories/csi/csi_phase2/civicis\%20russia\%20eng.pdf.

Yurchak, A. 2006. Everything Was Forever, Until It Was No More: The Last Soviet Generation. Princeton, NJ: Princeton University Press. 